\title{
Factors influencing to formation of geosystems of southern slope of the Greater Caucasus in the Republic of Azerbaijan and assessment of landscape-environmental capacity
}

\author{
Jahan Siradj Mammadova \\ Azerbaijan State Pedagogical University, \\ 68 Uzeyir Hajibeyov St, Baku, AZ1000, Republic of Azerbaijan \\ $\square$ sirac.memmedov54@mail.ru
}

\begin{abstract}
The Azerbaijani part of the Greater Caucasus consists of mountain ranges, mountainous depressions and sloppy plains. Different types of relief forms and landscapes have been formed during the repetition of endogenous and exogenous processes that have emerged as a result of the mutual influence of internal and external forces on the relief. The factors which influence the southern slope geosystems of the Greater Caucasus were first studied by us. Landscape-ecological assessment of the area was carried out using suitable, satisfactory, tense, crisiscritical and standard criteria, and a landscape map was compiled on its basis. The materials include the steppe expedition data. The applied methods are landscape-geomorphological, historical, comparative, mathematical-statistical, cartographic. Resistance of natural landscapes to anthropogenic influences is determined.
\end{abstract}

Keywords: Azerbaijan, Greater Caucasus, mountain geosystems, ecological potential, ecological assessment, landscape-ecological assessment, mudflow, landslide

\section{Introduction}

Within the territory of Azerbaijan, on the southern slope of the Greater Caucasus natural landscapes have been changed and replaced by modern forms where the population is densely populated, economic areas, as well as the transport network developed, the rapid growth of anthropogenic factors, and natural disasters, such as active floods, landslide, avalanche, etc., occur intensively. The components and features of geosystems in the area, and environmental instability of natural environment are associated with anthropogenic impacts which is constantly becoming strong. From this point of view, the assessment of mountain geosystems and their landscape-ecological capacity has become one of the actual problems of geography in modern age. 


\section{The object of research}

The southern slope of the Greater Caucasus extends to the east (Girdmanchay basin) from the west (Georgian border) at $220 \mathrm{~km}$ within the territory of Azerbaijan. The northern part of the area passes through Greater Caucasus watershed, the southern one passes through the north part of Ganikh-Eyrichay depression.

The southern slope of the Greater Caucasus does not create a zone with the same width and has a wide variety of sizes along the slope. The largest parts of the southern slope are in the east and west, and they are $25-30 \mathrm{~km}$ length. The narrowest part of the slope is approximately in its central part - Dashagilchay basin and it is up to $10 \mathrm{~km}$ width. In the southern slope of Caucasus ranges the watershed part consists of narrow, high-prone peaks. The relief of the slope starts from 500-600 m from absolute height and rises up to $4466 \mathrm{~m}$ (the Bazarduzu peak). The southern slope of the Greater Caucasus is bordered by the Main Watershed in the north from orographic point of view, and in the southwest by Ganikh-Eyrichay sloppy plain.

\section{Modern scientific-theoretical and methodological bases of research}

N.A. Qvodzetski, A.Q. Isachenko, V.S. Preobrojenski, N.L. Beruchashvili, V.I. Bulatova, I.M. Mamay, A.V. Melnik, B.A. Budagov [1-3], A.A. Mikayilov, M.A. Museyibov, E.K. Alizade [1;4] and other scientists have made great contributions to the research of mountainous lands landscape.

\section{The main purpose of the research}

It is the evaluation of modern geosystems of southern slope of the Greater Caucasus and their landscape-ecological potential.

To achieve the goal, the following tasks have been proposed:

- comparative analysis of modern scientific-theoretical and methodological problems of complex landscape researches in mountain geosystems;

- studying the impact of economic landscapes and settlements on natural landscape complexes;

- assessment of landscape-ecological potential in mountain geosystems.

\section{Analysis}

One of the important tasks of modern landscape science is to achieve sustainable development of natural geosystems, at the same time to prepare the scientific foundations of creating ecologically safe, highly productive agrolandscapes. Solution of this problem is also depending on efficient use of existing geosystems, the study of exodynamic processes occurring in them, and preparation of scientific bases of environmental problems of landscape complexes, as the landscape feature is formed under the complex interactions of its natural components. Therefore, the deterioration caused by any anthropogenic impact in a particular landscape structure necessarily leads to the change of lithogenic, hydrochloric bases of its 
natural potential and biotic change. Ecological deterioration to any part of the natural complex will necessarily lead to the ecological change of geosystem structure.

The factors influencing to formation of modern landscape. Geological and geomorphological conditions of southern slope of the Greater Caucasus, can be attributed by neotectonic movements observed intensively, its climate, morphometric indicators, flood accidents, economic activity of people, etc.

1. Geological and geomorphological conditions of the area. The southern slope of the Greater Caucasus has a rather complicated geological structure. The Mesozoic and Cenozoic sediments which spreads widely in the Alpine Zone form large tectonic structures (anticlinal, synclinal, isoclinal, overthrust, in the west horst-synclinal, horst-anticlinal ridges, graben-synclinal depressions). Especially, Zagatala-Govdagh synclinorium which consists of the Cretaceous period rocks lies to a big area and combines numerous ranges, ridges, intermountainous depressions in itself. Its northern part covers the Tinov-Rosso-Garagaya district [1]. The highest peaks are Tinov-Rosso, Kuton, Garagaya, Tufan, Babadag, Bazarduzu and others, it covers the areas which are up to 3400-4466 m high.

From Demiraparanchay to the East, morphostructures split more sharply, chalk sediments increase, there are Babadagh horst-anticlinorium, Govdagh horst-synclinorium, Guzduchay-Alatash horst-anticlinorium ranges. From the Demiraparanchay to the West, the relief is very steep, the main reason for it is that Southern microplate and Skif microplate has been exposed to folding in the collision zone.

The upstream part of the river consists of narrow streams and extends in the middle and lower parts. In the middle and highland zone the river valleys are 700-900 $\mathrm{m}$, and 250-300 $\mathrm{m}$ in the lower zone [2].

The alluvial-proluvial sediments observed in the river valleys cover large areas such as Demiraparanchay, Balakenchay, Vandamchay and Mazimchay. At the same time, Balakenchay and Kishchay have moraine sediments at the depths of 30-100 m. On top of the highland, jurassic sandstone and limestone rocks are commonly encountered [3]. From a geological point of view, from the east to the west the sediments on the southern slope are superior, while the traces of the lower jurassic period are observed in the Alpine zone. In general, we can say that as a result of interaction of geomorphological features of the relief with one another, the altitude landscapes are violated, and their horizontal structure becomes complicated [4].

2. Intensively observed neotectonic movements. One of the factors that play an important role in formation of mountainous landscapes is neotectonic movements. The impacts of neotectonic movements on the southern slope landscape of the Greater Caucasus have been studied. Intensive repetition of natural destructive processes leads to disintegration of relief, transformation of landscape complexes, replacement of natural landscapes to anthropogenic landscapes.

Development of landscape and its morphological parts on the southern slope of the Greater Caucasus has a gradual character, and the change term of its structure depends on taxonomic level of natural terrain complexes, and only facies are exposed to the most rapid and short-term changes. It takes a long time to replace the landscape structure with a completely new one. As a result of devastating natural phenomena, the structure of the landscape and its morphological 
sections is changed relatively quickly. In landscape complexes consistently new elements, new facies emerge, and it shows the changes to the appearance of new landscapes in the place of old landscapes.

3. The climate conditions of the area. The total solar radiation in the southern slope of the Greater Caucasus changes between $125-145 \mathrm{kcal} \mathrm{cm} /$ year. The active temperature more than $10{ }^{\circ} \mathrm{C}$ is $450-800{ }^{\circ} \mathrm{C}$ in total. Humidification index (Md) in the research area varies from 0.15 to 0.60 [5].

Table 1

Evaluation of climate indicators on the landscape zone of the South Caucasus along the territory of Azerbaijan

\begin{tabular}{lcccccc}
\hline \multicolumn{1}{c}{$\begin{array}{c}\text { Names of } \\
\text { landscape zones }\end{array}$} & $\begin{array}{c}\text { Amount of } \\
\text { precipita- } \\
\text { tion, } \mathbf{m m}\end{array}$ & $\begin{array}{c}\text { Total of } \\
\text { average } \\
\text { daily tem- } \\
\text { perature, } \\
\text { a day }\end{array}$ & $\begin{array}{c}\text { Average } \\
\text { temperature } \\
\text { of July, }{ }^{\circ} \mathbf{C}\end{array}$ & $\begin{array}{c}\text { Average } \\
\text { temperature } \\
\text { of January, } \\
{ }^{\circ} \mathbf{C}\end{array}$ & $\begin{array}{c}\text { Number of } \\
\text { days below } \\
\mathbf{0}{ }^{\circ} \mathbf{C}\end{array}$ & $\begin{array}{c}\text { Number of } \\
\text { days with } \\
\text { snow cover }\end{array}$ \\
\hline $\begin{array}{l}\text { The forest and forest- } \\
\text { bushes of foothills }\end{array}$ & $400-600$ & $300-330$ & $24-26$ & $1 ; 2$ & $40-55$ & $20-40$ \\
\hline $\begin{array}{l}\text { The forests of the low } \\
\text { highland }\end{array}$ & $600-1000$ & $250-300$ & $22-24$ & $0 ; 1$ & $60-75$ & $50-80$ \\
\hline $\begin{array}{l}\text { The forests of the mid- } \\
\text { dle highland }\end{array}$ & $1000-1200$ & $200-250$ & $20-22$ & $0 ;-2,5$ & $80-120$ & $100-130$ \\
\hline Subalpine meadows & $1200-1400$ & $200-150$ & $15-20$ & $-2,5 ;-5$ & $130-145$ & $140-160$ \\
\hline Alpine meadows & $1000-1200$ & $130-100$ & $10-15$ & $-5 ;-10$ & $150-170$ & $160-180$ \\
\hline Subnival & $600-800$ & $80-50$ & $5-10$ & $-10 ;-12$ & $180-200$ & $190-200$ \\
\hline Nival-rocks & 600 & 50 & 5 & -12 & 200 & 220 \\
\hline
\end{tabular}

Strong rains on the southern slope of the Greater Caucasus are observed in May and July, the precipitation with average intensity $<0.1 \mathrm{~mm} / \mathrm{min}$ is very frequent $(52 \%)$, the precipitation with $0.31-0.50$ and $0.51-1 \mathrm{~mm} / \mathrm{min}$ is 7.7 and $1.8 \%$ respectively. However, the precipitation with up to $0.1 \mathrm{~mm} / \mathrm{min}$ is more likely to occur in April and October. The precipitation with more than $0.25 \mathrm{~mm} / \mathrm{min}$ is mainly recorded in June. All data is summarized in Table 1.

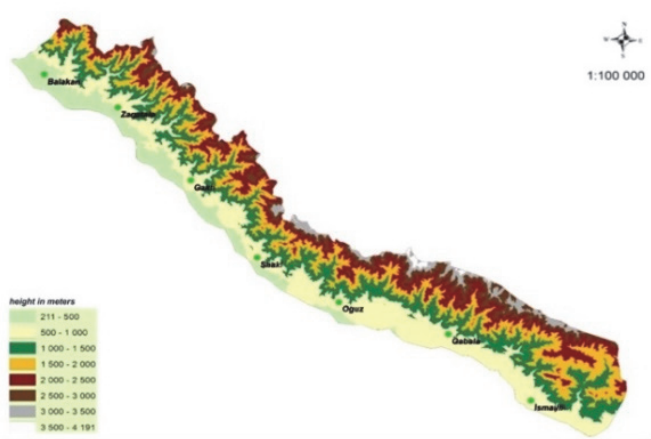

Hypsometric map

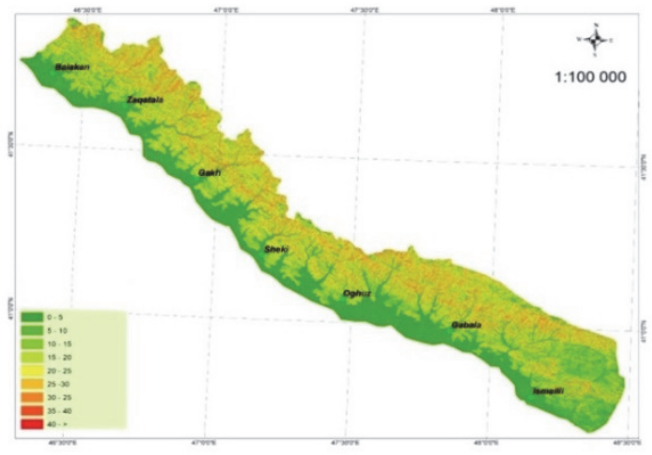

Inclination map

Figure 1. Hypsometric and inclination maps of the southern slope of the Greater Caucasus within the territory of Azerbaijan

4. Morphometric indicators of the area. It is very important to consider the hypsometric indicators of the area during the assessment of the landscapeecological potential of the southern slope in modern age. For this purpose, digital 
models of terrain relief have been established by us based on aerospace images of the surveyed area, with the help of ArcGIS 10.1 software in the GIS environment.

The morphometric parameters were used to study relief forms using the software described above. So, firstly taking into consideration the altitude parameter, hypsometric and inclination maps of the southern slope of the Greater Caucasus have been compiled by us (Figure 1).

5. Flood accidents repeating in the area frequently. Flood accidents are one of the factors that play a special role in the formation of modern landscapes on the southern slope of the Greater Caucasus. The geological-tectonic conditions, the amount of precipitation, as well as the crumbles, placers, avalanches, landslide, etc., play a great role in the development and distribution of floods that are effective in the formation of existing landscapes in the study area. Floods of natural origin are formed as a result of erosion, landslide, crumble and avalanche, and floods of anthropogenic origin, as well as agricultural and technogenic processes.

Development of floodplains in the study area is evident in the basins which refer to upper branches of Sarıbash village and in the basins of the Kurmuk river, between Mukhakhchay and Filfilchay rivers [6]. Along with them, Akvaychay (source of the Bulanigsu river), Garagayachay (source of Shinchay), Malukudchay (source of Filfilchay) and others, nival-subnival in mountainous region, Garaguzeychay (source of Gaynarchay), the source of Sari Guneydere river (Kishchay basin), mountain-meadow in mountainous region of Koshanchay (Kuncutchay Basin), on the left eastern slope of Kishchay valley in Kishchay region, Enischay basin, on the northern slope of Yarpizbazar mountain near Ilisu village and other areas of the mountain-forest landscape flood accidents form. The intensification of flood accidents plays important role in the formation of the relief, landscape and so on [7]. Such cases, flood and its destructive power that is effective on the dynamics, formation, transformation of the landscape are determined by the volume of its suspended materials.

6. Anthropogenic activity. One of the factors influencing to formation of modern landscape are anthropogenic effects. As a result of population impact on the mountainous and foothill areas of Azerbaijan, landscape differentiation has happened. The devastating flood accidents observed in the highland geosystems have great economic damage to the region, and natural landscape complexes are exposed to change.

Structural features of landscapes are changing due to economic activity of people. Due to the fact that the foothill zones are adopted more, here distortions emerge in the landscape complexes, and the first significant change takes place in the vegetation and fauna of that area. As a result of anthropogenic impact, new features appear in the ground cover [8].

In some regions where irrigation agriculture is developing, some features of the soil humidification regime are subject to change, the level of groundwater is rising - microclimate conditions vary considerably. As a result of increasing impact of people on the southern slopes landscape complexes in the Greater Caucasus, expansion of the area appropriation more than normal and growing of human impact on natural territorial complexes lead to negative ecogenic relief forms. As a result, the balance of landscapes is sharply distorted. To reveal such 
problems in time, investigating mountain landscapes and compiling the landscape map of the area are of great importance.

The landscape map of the southern slope of the Greater Caucasus. It is important to determine the natural potential and differential properties of mountain geosystems on altitude zones during the research. Depending on the lithological content of rocks, fragmentation and density of the relief, slopes inclination, the climatic conditions of the area, its soil and vegetation, population settlement, as well as their economic activity the differential features of modern landscape can be determined. The assessment of natural resources in mountain geosystems should be primarily carried out on the components [9]. So, depending on the altitude, development process of differentiation on the main indicators of natural resource potential in geosystems should be calculated. For this purpose, the degree of adopting high, middle and low highlands on the main components of landscape, and development directions of planting areas and livestock should be determined. To define landscape and ecological potential, firstly, the landscape map of the area should be developed. For this pupose, the landscape map of the southern slope of the Greater Caucasus (Figure 2) have been compiled by us using landscape map of Azerbaijan compiled by A.A. Mikayilov, E.K. Alizade, M.C. Ismayilov and others on the landscape map of Azerbaijan, as well as all actual materials obtained during the research, applying modern GIS technologies on images taken on aerospace monitoring systems (using the ArcGIS 10.1 software).

\section{Landscape types:}

A. HiGH MOUNTAIN LANDSCAPES WITH COLD, HUMID CLIMATE:

\section{Nival landscapes:}

1. Nival-rocky landscapes deprived of soil-vegetation cover in medium and partly dissected slopes of high mountain.

2. The slopes deprived of the soil-vegetation cover in the intensive dissected glacial slopes of high mountain and slopes where crumble-placers develop dynamically.

II. Subnival landscapes:

3. The soil-vegetation cover of the middle and weakly dissected slopes of high mountain and its bedrocks on the surface.

4. Alpine lowlands in the shape of stains on weathering materials in weakly developed mountain-lowland soils of medium and intensive dissected steep slopes of high mountain.

5. Steep stingy slopes, deprived of intensive dissected soil-vegetation of high mountains.

B. MOUNTAIN-LOWLAND LANDSCAPES WITH HUMID AND MILD-HUMID CLIMATE:

III. Alpine lowlands:

6. The plants such as bromus, triple clover, meadow fescue, poaceae in the rewashing mountain-lowland lands at a low-density of intensively dissected, very steep, partly steep and stingy mountain slopes.

7. The plants such as lowland fescue, thyme, triple clover and bromus in the rewashing mountain-lowland lands at a low-density of steep mountain slope which is intensively dissected and exposed to erosion.

8. Island-shaped mountain meadows in the mountain-lowland lands that devoloped weakly of the rock juts of intensive dissected (bare), steep rockystingy slopes. 
9. The plants such as buttercup, thyme and clover in the erosional mountainmeadow lands of mid-dissected, steep (stingy) mountain slopes.

$I V$. Subalpine lowlands:

10. The plants such as foxtail grass, triple clover, lowland fescue and different grasses in the dense mountain-lowland lands of synclinal intermountain depressions and undissected valley bottoms of high mountains.

11. The plants such as triple clover, fescue, poaceae in the mountain-lowland lands of weakly-dissected landslide slope sod.

12. The plants such as lowland fescue and bromus in the soddy mountainmeadow lands of mid-dissected landslide slopes.

13. The plants such as thyme, clover, triple clover and different herbs in the soddy mountain-lowland lands of mid-dissected, mid-inclined mountain slopes.

14. Subalpine lowlands after the forest (thyme, triple clover) in the lessinclined, gravely lands of intensive dissected, steep mountain slopes.

15. The plants such as triple clover and different herbs in the soddy mountainlowland lands of mid-dissected, mid-inclined landslide slopes.

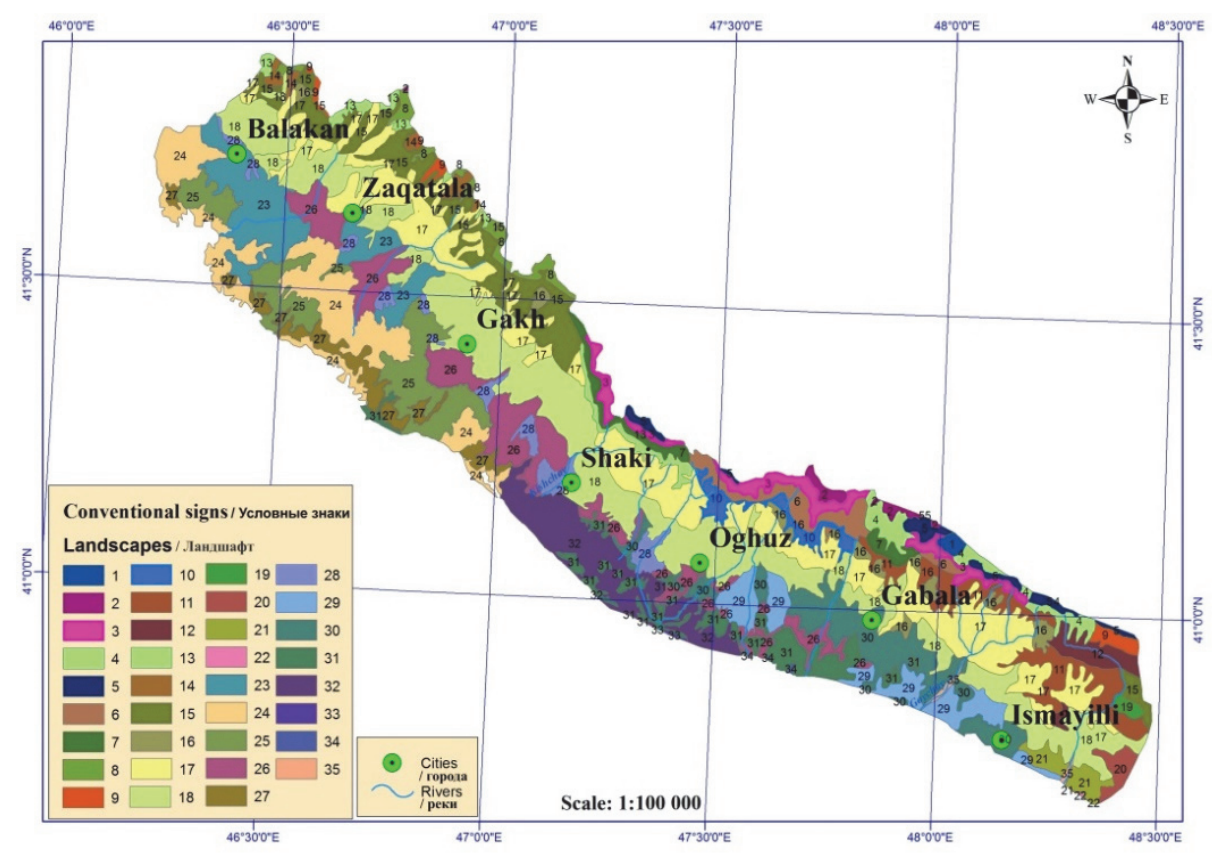

Figure 2. Landscape map of the southern slope of the Greater Caucasus within the territory of Azerbaijan

C. MiLD-HUMID MOUNTAIN-FOREST LANDSCAPES:

$V$. Beech-hornbeam and oak-hornbeam forests of middle mountain and partly high mountain:

16. Beech-oak-hornbeam forests in the brown mountain-forest lands of intensive dissected high mountain slopes.

17. Beech-hornbeam and oak-hornbeam forests in the brown mountainforest lands of mid-dissected, mid-inclined low and middle mountain slopes.

18. Beech-hornbeam-oak forests in the brown mountain-forest lands of middissected, mid-inclined low and middle mountain slopes. 


\section{LANDSCAPE OF MIDDLE AND LOW MOUNTAİNS WITH HUMID CLIMATE:}

VI. Forest-steppe, steppe and mountain-lowland landscapes of low and middle mountains:

19. Paliurus, dog rose bushes and with wormwood-different herbs meadowsteppes aftr the forest in the brown lands of mid-dissected landslide slopes of intermontane depressions.

20. Oak-hornbeam forests and bushes after the forest, the lowlands with different herbs in the brown lands of weakly dissected landslide slopes.

21. Barberry, dog rose, blackberry bushes and the lowland-steppes with different herbs after the forest in the brown and mountain-lowland lands of middissected landslide slopes.

22. Hornbeam-oak and oak-hornbeam forest bushes, thin lowland-steppes in the mountain-brown lands of intensive dissected slopes.

E. LANDSCAPES OF ACCUMULATIVE PLAİNS WITH MILD-HUMID CLIMATE:

VII. Forest, bush-meadow and forest-steppe landscapes of accumulative plains:

23. Oak-hornbeam forests which were replaced with seliteb area - orchards and plantation agrolandscapes in the brown lands of weakly dissected inclined plains.

24 . Bushy steppes after the forest which were replaced with seliteb area orchard and plantation agrolandscapes in the brown lands of undissected, lessinclined, terraced plains.

25. Meadow-bushy steppes after the forest were replaced with orchard-plantation agrolandscapes in the brown lands of undissected, less-inclined, terraced, alluvialproluvial plains.

26. Bushes (paliurus, dog rose, blackberry) and wormwoods and different herbs after the forest in the brown lands of weakly dissected, high proluvial plains.

27. Seliteb-plantation landscapes and white-grassed steppes with wormwood in the brown lands of weakly dissected, smooth plains.

28. The bushes and steppes with different herbs which are used as a pasture in the brown lands of undissected, inclined proluvial-stoned plains.

29. Oak-hornbeam forests in the brown lands of mid-dissected, less-inclined, alluvial-proluvial plains.

30. Oak-hornbeam forest bushes and lowland-steppes which were changed into agrolandscapes in the brown lands of weakly dissected, alluvial-proluvial plains.

31. Oak-hornbeam forests and bushes in the alluvial-lowland lands of intensive dissected, terraced plains.

32. After the forest, the forest bushes along the river and white-grassed wormwood plants which are changed into orchard-plantation landscapes in the alluviallowland lands of weakly dissected, less-inclined, smooth plains.

VIII. The landscapes of arid-denudation low mountains and depressions:

33. Paliurus, blackflower, pomegranate and wormwood-white grassed steppes in the dark-chestnut (grey-brown) and brown lands of undissected, less-inclined low-mountains.

IX. Dry steppe and xerophyte-steppe landscapes of denudation-accumulative plains:

34. The plants with wormwoods-white grass, wormwood-ephemerial plants in the chestnut (grey-brown) lands of wekly dissected, less-inclined, flat plains. 


\section{Intrazonal landscapes of accumulative plains:}

35. Lowland-steppe, lowland-bog and lowland-bush in the alluvial lowlands of mid-dissected river valleys.

\section{The assessment model of landscape-ecological capacity}

The perspectives of solving the ecological problems of the southern slope of the Greater Caucasus is related to the continuation of landscape-ecological researches. The studies in the research area which were carried out by us once again prove that the ecological balance of the landscape depends on ecological approach to the studying geosystems and their components and properties and it depends on the current level of ecological stability degradation in the natural environment which is the result of constantly-increasing anthropogenic impact.

Environmental aspects of landscape surveys are related to the deterioration of the environment in which people pay for daily activity and material assurance. One of the most important issues of landscape-ecological researches is the assessment of landscape complexes, their natural potential, the degree of anthropogenic change, the environmental risk and the state of the geosystems as a whole.

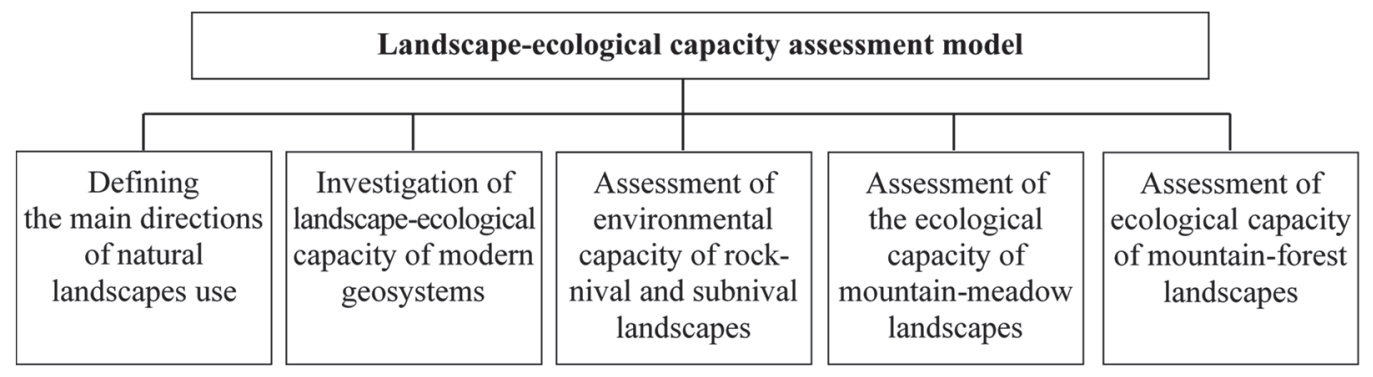

Figure 3. The assessment model of landscape-ecological capacity of modern geosystems

Taking into account the factors we have mentioned, we have prepared model for the assessment of the landscape-ecological potential of modern geosystems in order to assess the modern geosystems of the Greater Caucasus and their landscapeecological capacity (Figure 3).

\section{The assessment of landscape-ecological capacity}

While determining the main directions of natural landscape use in southern slope of Greater Caucasus, assessing the landscape-ecological potential of the modern geosystems, we have prioritized the results of researches in the area, as well as traditional methods, however we preferred using the most modern approaches and methods [10]. The reason is that research techniques and geographical maps based on them before us were of a general nature and reminded a collection of laconic information for a particular area. Relief digital models were previously obtained by vectorization of topographic maps or using topographical shooting materials. At present, this method is not considered as effective because it is a time consuming process for a large area. From this point of view, such investigations have been carried out in recent years with the distance probe method. It should be noted that the maps compiled by modern Geographic Information Systems play a role 
as a numerous data collection for the research area, as well as, an updated multistage database, which further enriched by adding new information.

In the modern geosystems, as a result of the various ecological processes affecting the ecological capacity of landscapes, as well as the decoding of aerocosmic images we have determined that mountain-forest and mountain-meadow landscapes are expanding, and water-erosion processes are developing on inclined slopes. Taking these into account, we have compiled an environmental potential map of the southern slope landscapes of the Greater Caucasus and combined the ecological capacity of landscapes in five groups - extreme, low, medium, relatively high, high (Figure 4).

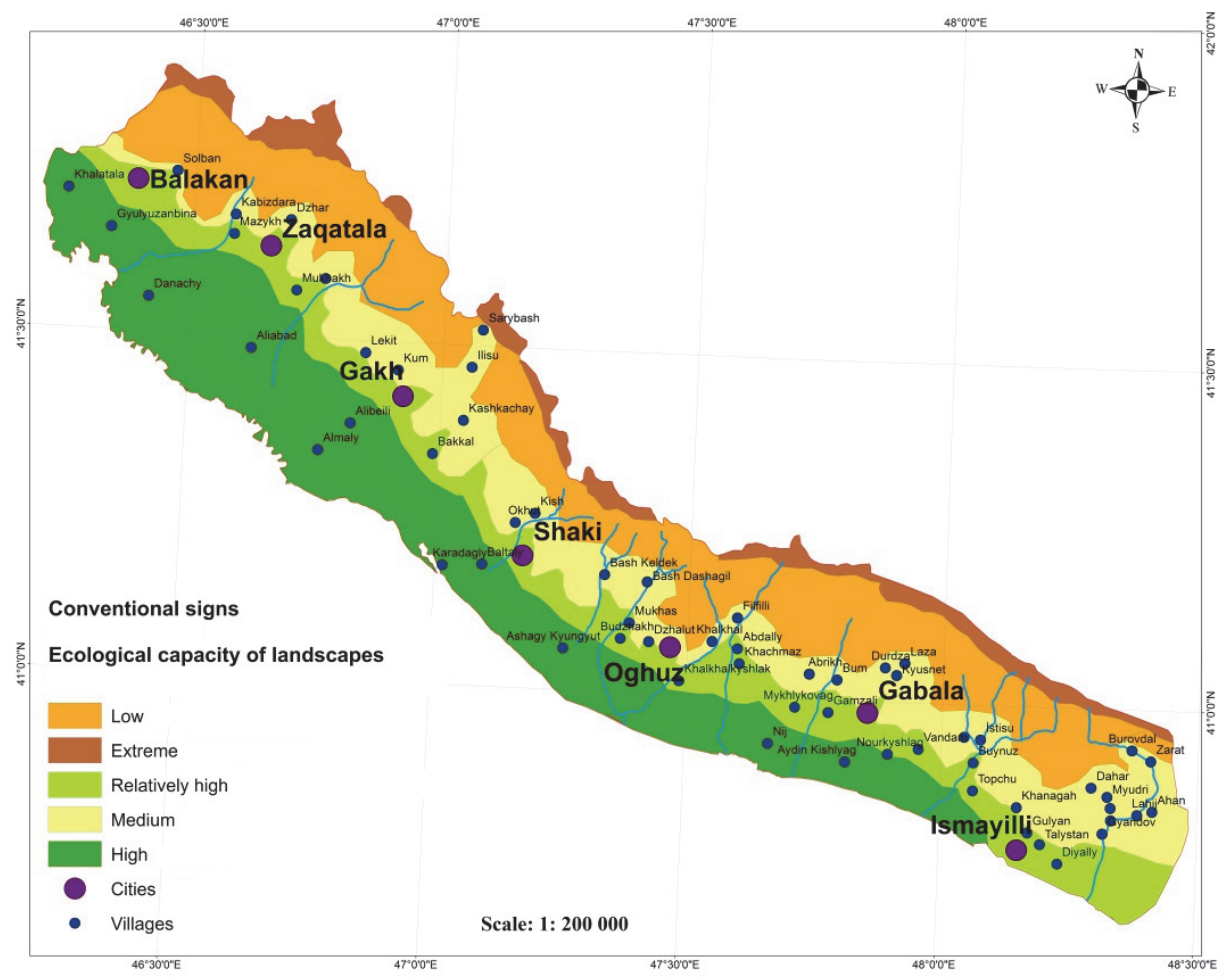

Figure 4. The ecological-capacity map of the southern slope landscape of the Greater Caucasus within the territory of Azerbaijan

It should be noted that the nival-subnival landscapes are distinguished by their ecological stability in the region. Of course, this is due to the difficult appropriation of the area. This includes erosion, denudation, high-intensity, mixedrocky mountains. Nival-glacial and erosion-glacial mountains are characteristic for this area and are covered by the Main Caucasus, Yan, Shahdagh ranges. As a result of intensive denudation processes, dissected rocks from rocky areas are collected into the slopes of the peaks, as well as in kars and cirques. In these zones, there are nival and subnival landscapes on the ancient glacier relief and relief. Almost, nival-subnival landscape has mainly developed in Akhvay, Seyidyurd, Chagil and other mountainous regions.

Intensive development areas of floodplain landscapes are mainly nival-subnival and mountain-lowland zones, where there are the most appropriate physical-geo- 
graphical features for their formation. In nival-subnival and mountain-meadow landscapes, gravitational, infiltrational and glacial floodplains are mainly dominant, however, in mountain-forest landscape zone fluvial and gravitational-infiltrational floodplains are dominant [11]. In the large area within the altitude landscape zone, continental facies of the $4^{\text {th }}$ century are widely spread and they (glaciers, alluvialproluvials, alluvial-delluvial and other origin rocks) are involved as the main source of flood and erosion materials [12].

Mid-powerful floods has been happening for the last 15 years in which in the middle and low-mountains bushes, steppes, forest-steppes, and arid sparse forests are dominant, population settlement is dense, transport networks are growing rapidly, dryland farming spreads widely, in the areas where anthropogenic factors are strong. In the areas where intense flooding is repeated, forest cover is sparse, high inclination of the middle mountainous region (relatively low mountains), mainly due to the anthropogenic factor, rapid decomposition of forests, small mountain bushes is observed.

The landscape ecological assessment has been conducted taking into consideration the impact of the economic areas on the separate landscape types of the research area, appropriation degree of the area, and its durability degree against natural and anthropogenic factors. As you can see from Table 2, high mountain landscapes are considered unfit for farming. Mountain-meadow landscapes are used as grazing and grassland, and the degree of appropriation is seasonal. In mountain-forest landscapes, seliteb, seliteb-orchard plantations are widely spread and the degree of their appropriation has been highly appreciated.

Table 2

Ecological assessment of the landscape of the southern slope of the Greater Caucasus within the territory of Azerbaijan

\begin{tabular}{clccccc}
\hline No. & \multicolumn{1}{c}{ Landscape types } & $\begin{array}{c}\text { Area, } \\
\mathbf{k m}^{2}\end{array}$ & $\begin{array}{c}\text { With } \\
\text { percent, } \\
\text { \% }\end{array}$ & Farm use & $\begin{array}{c}\text { Appropriation } \\
\text { degree }\end{array}$ & $\begin{array}{c}\text { Ecological } \\
\text { assessment } \\
\text { of the } \\
\text { landscape }\end{array}$ \\
\hline 1 & $\begin{array}{l}\text { High mountain landscapes } \\
\text { with cold, humid climate }\end{array}$ & 385,4 & 5,1 & - & Crisis \\
\hline 2 & $\begin{array}{l}\text { Mountain-lowland landscapes } \\
\text { with humid and mild-humid } \\
\text { climate }\end{array}$ & 1260,5 & 16,8 & $\begin{array}{c}\text { Grassland } \\
\text { summer } \\
\text { pastures }\end{array}$ & Seasonal & Critic \\
\hline 3 & $\begin{array}{l}\text { Mountain-forest landscapes } \\
\text { with mild-humid climate }\end{array}$ & 2466,2 & 32,9 & $\begin{array}{c}\text { Seliteb, } \\
\text { seliteb-orchard } \\
\text { plantations }\end{array}$ & Seasonal & Tense \\
\hline $\begin{array}{l}\text { Middle and low mountain } \\
\text { landscape with mild-humid } \\
\text { climate }\end{array}$ & 123,3 & 1,6 & $\begin{array}{l}\text { Seliteb-orchard, } \\
\text { vegetable sown } \\
\text { areas }\end{array}$ & High & Satisfactory \\
\hline 5 & $\begin{array}{l}\text { Accumulative plains land- } \\
\text { scape with mild-humid } \\
\text { climate }\end{array}$ & 3253,2 & 43,6 & $\begin{array}{l}\text { Seliteb-orchard } \\
\text { plantation }\end{array}$ & High & Convenient \\
\hline
\end{tabular}

In order to achieve the goal, we have used scientific works and obtained innovations of the scientists who researched in this field historically and we can come to such a conclusion that in the research area steppe and distance probe work were conducted before and the obtained data was studied with the interpolation method. At this time landscape ecological capacity was also taken into consideration [13]. 


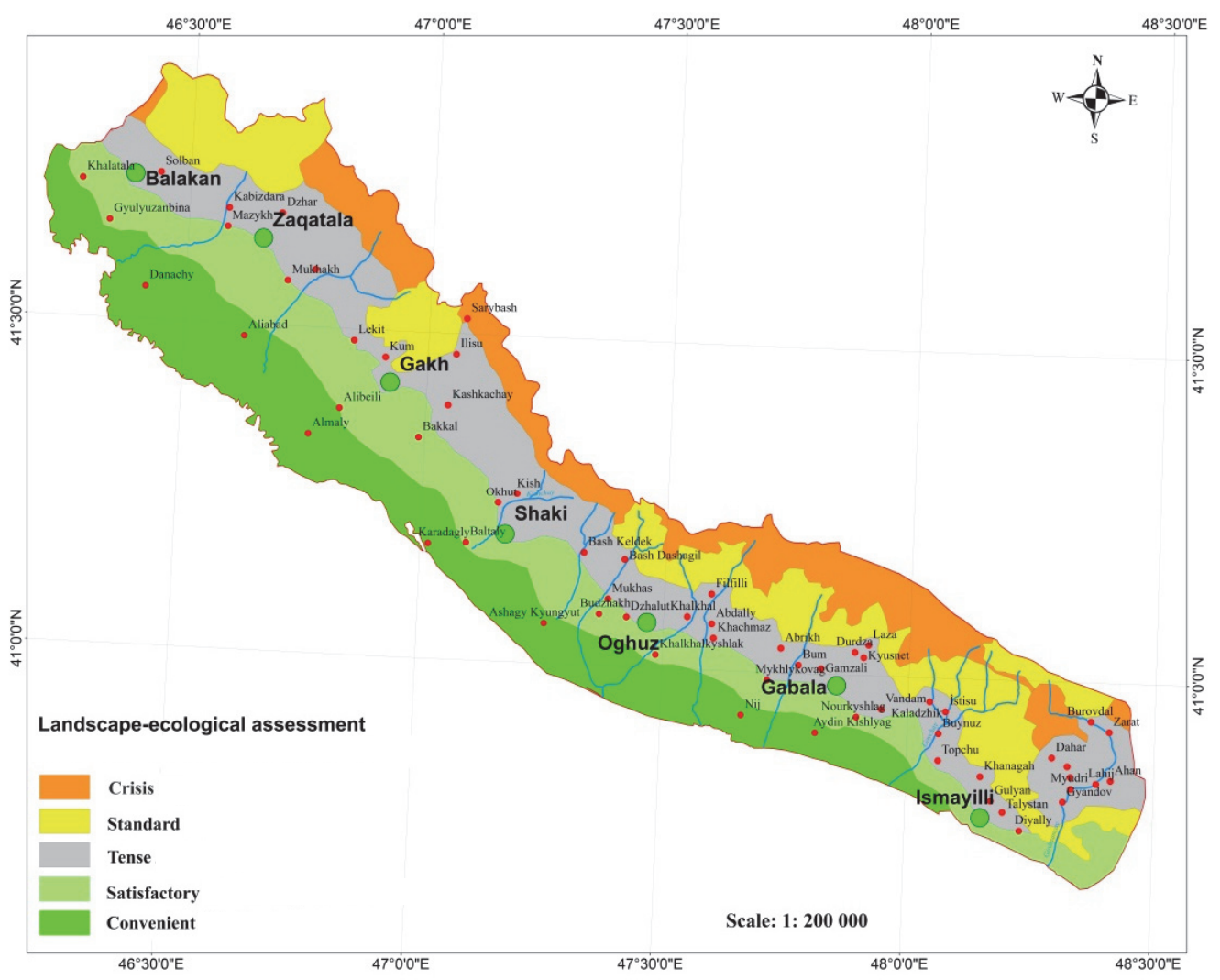

Figure 5. Landscape-ecological assessment map of the southern slope of the Greater Caucasus within the territory of Azerbaijan

Also, all obtained data was analyzed mutually and general results were prepared and the landscape-ecological assessment map of the research area was compiled by us (Figure 5). Thus, from landscape-ecological point of view, the southern slopes of the Greater Caucasus are divided into five groups: convenient, satisfactory, tense, crisis and standard.

\section{Conclusion}

Connected with the dynamics of population growth in Azerbaijan, global changes in climate, regular natural processes in relief, etc., there is always a change in the structure of the landscape. The self-development of the landscape is relatively slow. However, the mutual influence of external factors and internal processes accelerates the process of its formation, and thus, one landscape type is replaced by another one with certain changes.

The upper border of the forest areas on the southern slope of the Greater Caucasus is regularly exposed to anthropogenic impacts. That is, as a result of anthropogenic impact of the forest strip, the boundaries of the forests in the study area have gone down several hundred meters and are currently on the average 1800-2000 $\mathrm{m}$ above the sea level. Anthropogenic impacts, along with its transformations created at the lower and upper boundaries of the forest, also change the species of the forest content. 
Subnival landscapes of the high mountain in the southern slopes of the Greater Caucasus, which are distinguished by their intensive fragmented relief, lead to the collection of a large number of detrital materials on mountain slopes, floodplains as relief formation factor. The Jurassic clay shists, which can be easily weathered in the mountainous areas, collected in floodplains as detrital materials, and it creates a condition for destructive flood accidents in those areas.

The activity of the floodplains, which play a special role in the differentiation of landscape, is related to the composition of the rocks in the basins. The frequency of formation and repetition of the floods in the research area depends on the landscape zone. The power source of the floods consists of the landslide and landslide masses on the sandy-clay rocks of the paleogeneneogene. The dynamic development of the floodplain in the river basins, where the Jurassic clay shists are widespread, accelerates the denudation processes here.

\section{References}

[1] Budagov BA, Mamedov RM, Alizadeh EK. Natural and man-made disasters in the territory of Azerbaijan. News of the National Academy of Sciences of Azerbaijan. Series: Earth Sciences. 2008;(1):121-133. (In Russ.)

Будагов Б.А., Мамедов Р.М., Ализаде Э.К. Природные и техногенные катастрофы на территории Азербайджана // Известия Национальной академии наук Азербайджана. Серия: Науки о Земле. 2008. № 1. С. 121-133.

[2] Budagov BA. Constructive proposals for the Kishchay and its flood. The achievements of geography science (vol. 1). Baku: Nafta-Press; 2007. p. 218-226. (In Azeribaijan.)

[3] Budagov BA. Sovremennye estestvennye landshafty Azerbaidzhankoi SSR [Modern natural landscapes of the Azerbaijan SSR]. Baku: Elm Publ.; 1988. (In Russ.)

Будагов Б.А. Современные естественные ландшафты Азербайджанской ССР. Баку: Элм, 1988. 134 с.

[4] Alizadeh EK, Guliyeva SYu, Kuchinskaya IYa, Tarikhazer SA. Landscape-ecogeomorphological problems of assessing the geodynamic intensity of mountain systems. Proceedings of the Geo-Regional Society of Azerbaijan. 2013;XVIII:36-43. (In Russ.) Ализаде Э.К., Гулиева С.Ю., Кучинская И.Я., Тарихазер С.А. Ландшафтно-экогеоморфологические проблемы оценки геодинамической напряженности горных систем // Труды Георегионального общества Азербайджана. 2013. T. XVIII. C. $36-43$.

[5] The geography of the Republic of Azerbaijan (vol. 1). Baku: Avropa Publ.; 2014. (In Azeribaijan.)

[6] Mammadova CS. Transformation of landscapes in the floodplain (in the example of southern slope of the Greater Caucasus). Geography and natural resources. 2016;(1): 38-43. (In Azeribaijan.)

[7] Mardanov IE. Classification of the formation factors of flood (on the example of the southern slope of the Main Caucasus Range). News of the Academy of Sciences of Azerbaijan. Series: Earth Sciences. 1969:118-123. (In Russ.)

Марданов И.Э. Классификация факторов формирования паводка (на примере южного склона Главного Кавказского хребта) // Известия Академии наук Азербайджанской ССР. Серия: Науки о Земле. 1969. С. 11-23.

[8] Suleymanov MA. Geographical regularity of natural and anthropogenic landscapes of Azerbaijan. Baku: Abilov, Zeynalov and sons; 2005. (In Azeribaijan.)

[9] Mammadov RM, Ismailov MC. Evaluation of natural potential of landscapes in Azerbaijan and its effective utilization. Evaluation of natural resource potential of geosystems and its efficient use in the context of global climate change. 2013;XVIII:10-20. (In Azeribaijan.) 
[10] Mammadova CS. Landscape characteristics and mapping methods on the southern slope of the Greater Caucasus. Pedagogical University News. 2015;(2):73-77. (In Azeribaijan.)

[11] Mamedalizade MO. Study of the landscapes of the basins of the selenos rivers of the southern slope of the Greater Caucasus (between the Mukhakhchaya and Filfilichaya rivers) using aerial photographic materials (Dissertation of the Candidate of Geographical Sciences). Baku; 1986. (In Russ.)

Мамедализаде M.O. Изучение ландшафтов бассейнов селеносных рек южного склона Большого Кавказа (междуречье Мухахчая и Фильфиличая) с использованием материалов аэрофотоснимков: дис. ... канд. геогр. наук. Баку, 1986. 169 с.

[12] Ismayilov MC, Mammadbeyov ES, Yunusov MI. Large intermorphostructural transboundary areas and their ecological potential. Works of the Azerbaijan Geographical Society. 2008;XII:90-96. (In Azeribaijan.)

[13] Mammadbeyov ESh, Yunusov MI, Gurbanov TR. Influence of anthropogenic change of natural landscapes of the North-East slopes of the Greater Caucasus on ecological diversity. Works of the Azerbaijan Geographical Society. 2007;XI:45-54. (In Azeribaijan.)

\title{
Article history:
}

Received: 15.03 .2020

Revised: 24.04.2020

\section{For citation:}

Mammadova JS. Factors influencing to formation of geosystems of southern slope of the Greater Caucasus in the Republic of Azerbaijan and assessment of landscape-environmental capacity. RUDN Journal of Ecology and Life Safety. 2020;28(3):237-251. http://dx.doi.org/10.22363/2313-2310-2020-28-3-237-251

\section{Bio note:}

Jahan Siradj Mammadova, PhD in Geography, senior lecturer of the Department of General Geography of the Azerbaijan State Pedagogical University. E-mail: sirac.memmedov54@mail.ru

\section{Факторы, влияющие на формирование геосистем южного склона Большого Кавказа в пределах Азербайджанской Республики, и оценка ландшафтно-экологического потенциала}

\author{
Д.С. Мамедова
}

Азербайджанский государственный педагогический университет, Азербайджанская Республика, AZ1000, Баку, ул. У. Гаджибекова, д. 68

$\square$ sirac.memmedov54@mail.ru

Аннотация. Азербайджанская часть Большого Кавказа состоит из горных хребтов и впадин и наклонных равнин. Различные типы рельефных форм и ландшафтов Большого Кавказа сформировались в результате повторения эндогенных и экзогенных процессов, возникших в ходе взаимного воздействия внутренних и внешних сил на ре- 
льеф. Впервые изучены факторы, влияющие на геосистемы южного склона Большого Кавказа. Проведена оценка ландшафтно-экологического потенциала района с использованием подходящих, удовлетворительных, напряженных, кризисно-критических и стандартных критериев, на ее основе составлена ландшафтная карта. Использованы материалы степной экспедиции, ландшафтно-геоморфологические, исторические, сравнительные, математически-статистические, картографические методы. Определена устойчивость природных ландшафтов к антропогенным воздействиям.

Ключевые слова: Азербайджан, Большой Кавказ, горные геосистемы, экологический потенциал, экологическая оценка, ландшафтно-экологическая оценка, селевой поток, оползень

\section{История статьи:}

Дата поступления в редакцию: 18.03.2020

Дата принятия к печати: 24.04.2020

\section{Для цитирования:}

Mammadova J.S. Factors influencing to formation of geosystems of southern slope of the Greater Caucasus in the Republic of Azerbaijan and assessment of landscape-environmental capacity // Вестник Российского университета дружбы народов. Серия: Экология и безопасность жизнедеятельности. 2020. Т. 28. № 3. С. 237-251. http://dx.doi.org/ $10.22363 / 2313-2310-2020-28-3-237-251$

\section{Сведения об авторе:}

Мамедова Джахан Сирадж, кандидат географических наук, старший преподаватель кафедры общей географии Азербайджанского государственного педагогического университета. E-mail: sirac.memmedov54@mail.ru 